Boston University School of Law

Scholarly Commons at Boston University School of Law

Faculty Scholarship

Fall 2010

\title{
A Small Nation Goes to War: Israel's Cabinet Authorization of the 1956 War
}

Pnina Lahav

Boston University School of Law

Follow this and additional works at: https://scholarship.law.bu.edu/faculty_scholarship

Part of the Law Commons

\section{Recommended Citation}

Pnina Lahav, A Small Nation Goes to War: Israel's Cabinet Authorization of the 1956 War, 15 Israel Studies 61 (2010).

Available at: https://scholarship.law.bu.edu/faculty_scholarship/509

This Article is brought to you for free and open access by Scholarly Commons at Boston University School of Law. It has been accepted for inclusion in Faculty Scholarship by an authorized administrator of Scholarly Commons at Boston University School of Law. For more information, please contact lawlessa@bu.edu. 


\title{
BU School of Law
}

\section{A Small Nation Goes to War: ISRAEL'S CABINET AUTHORIZATION OF THE 1956 WAR}

\author{
From Israel Studies, Volume 15, Number 3, pp. 61-86 \\ Special Issue: \\ The Making of Israel Foreign Policy (Indiana University Press, Fall 2010) \\ Boston University School of Law Working Paper No. 10-37 \\ (November 4, 2010) \\ Pnina Lahav
}

This paper can be downloaded without charge at:

http://www.bu.edu/law/faculty/scholarship/workingpapers/2010.html 
Pnina Lahav

\title{
A Small Nation Goes to War: Israel's Cabinet Authorization of the I956 War
}

\begin{abstract}
The Suez War had long term ramifications for Israel's status in the Middle East and for its relations with the U.S., Europe, and the USSR. This article is a first segment in the examination of the interplay between military and diplomatic means deployed by Israel in its quest to consolidate the gains of the 1948 war and secure its sovereignty. It provides a detailed analysis of the Israeli cabinet deliberations as it reached the decision to authorize war. The article examines the cabinet's opinions on the language of the motion to go to war, the list of casus belli offered, the secret agreement with France and Britain which precipitated the war, considerations of possible complications, the theory of war and peace, the likelihood of regime change in Egypt, and the preparedness of the home front. It raises the question of the relevance of the comparative size and strength of a nation as it ponders the option of launching a war.
\end{abstract}

\section{BACKGROUND}

n 29 October i956, IsRael launched a War against Egypt. Two days later it became clear that Britain and France were Israel's senior partners, and that the central target of the two colonial powers was to restore their hold over the Suez Canal. ${ }^{1}$ A fearsome international storm erupted and the three belligerents quickly abandoned their grand plan and withdrew their forces. While short and militarily uneventful, the Suez War is generally considered a watershed event in the history of Middle East. It signaled the end of the colonial era and the beginning of the transformation 
of the region into a battleground between the U.S. and the USSR; thereby, the Arab-Israeli conflict intensified in ways hitherto unpredicted. The Suez War was also etched in the minds of Israel's decision makers and affected their decision making a decade later during the Six-Day War and, later, the Yom Kippur War. Its further significance lies in the fact that this was the first time Israel's cabinet approved a war since the establishment of the state in 1948.

Until recently, the voluminous scholarship on this war did not pay much attention to the Israeli cabinet deliberations authorizing the war. The perceived wisdom was that the ministers were privately informed by PM and Minister of Defense Ben-Gurion, and that the formal process of authorization was trivial. ${ }^{2}$ One reason for this assertion was that the cabinet protocols were classified and inaccessible; however, in 2008, the files were opened. ${ }^{3}$

The protocols reveal that even though the cabinet was aware that it was facing a fait accomplis it still deliberated vigorously and for the most part honestly and courageously. Ben-Gurion's confrontation with his cabinet was not easy, and during the deliberations he revealed his anxiety and foreboding. The protocols also reflect the unhappy condition of an insecure and dependent junior partner about to embark on a roller coaster. If Israel declined the French proposal it could have lost the generous support and cooperation of the French and the prospects of befriending Britain. If it joined the French plan it could gravely suffer the injuries of war while alienating the U.S., which most emphatically opposed the idea of war. There was also the temptation to seize an opportunity - join the allies and bring about a new Middle East order with a weakened Egypt and a stronger Israel. The protocols are also a testament to the painful historical experience of an eight-year old fledgling polity struggling to develop democratic features while experiencing pressures to maintain a centralized style of leadership in order to face the threats to its security and survival. ${ }^{4}$

Israeli constitutionalism places the decision to go to war in the hands of the executive branch. However, the nature of the cabinet as a microcosm of the majority parties in parliament may provide for a check on the prime minister and the military. The power of checks and balances inherent in the availability of deliberations is evident is these protocols, and should be studied as a model for the Israeli decision-making process activating the war-making powers. ${ }^{5}$ 


\section{THE COMPOSITION OF THE CABINET}

On Sunday 28 October 1956, Israel's cabinet held its regular weekly meeting. ${ }^{6}$ Ben-Gurion placed on the table a motion "to perform an action of several raids" the following day. ${ }^{7}$ Israel's coalition cabinet comprised 16 ministers: 9 from the leading Mapai party headed by Ben-Gurion; 2 representing each of the smaller parties - the National Religious Party (Mafdal), the United Labor Party (Achdut Haavoda), and the Israel Workers Party (Mapam); and one representative of the Progressive party, Minister of Justice Pinhas Rosen. Mapai members who participated in the deliberations were Ministers Zalman Aranne (Education and Culture); Levi Eshkol (Finance); Golda Meir (Foreign Affairs); Pinhas Sapir (Commerce and Industry); and Bechor Shalom Shetreet (Police). Of these, Eshkol, Sapir, and Meir constituted the small inner ring with whom Ben-Gurion shared power.

The National Religious Party was represented by ministers Yosef Burg (Postal Services), and Moshe Shapira (Religion and Welfare). The United Labor Party was represented by ministers Moshe Carmel (Transportation), and Israel Bar-Yehuda (Interior). These six, together with Pinhas Rosen, supported the motion but expressed various degrees of skepticism about its wisdom and effectiveness. Mapam, whose members opposed the motion, was represented by ministers Mordechai Bentov (Development), and Israel Barzilai, (Health).

Five months prior to these events the cabinet underwent a major change. Minister of Foreign Affairs Moshe Sharett, a strong voice for multilateralism and diplomacy, was ousted and replaced by Golda Meir, a staunch Ben-Gurion supporter, which tilted the pendulum in favor of belligerency. ${ }^{8}$ The ministers below will be referred to by name.

The cabinet protocols contain 42 dense pages and appear to be a verbatim transcript of the deliberations. Of these, Ben-Gurion's opening remarks accounted for Io pages. His response to the challenges and queries posed by the ministers occupied another 6.5 pages. Altogether, his words account for one-third of the entire protocol. The cabinet approved the motion, with the dissention of the two Mapam members. 


\section{THE MOTION: "A NUMBER OF RAIDS" OR A FULL FLEDGED WAR: WHAT'S IN THE TERM? OR: WHAT WAS THE CABINET VOTING FOR?}

Ben-Gurion's motion did not literally amount to a proposal to launch a war. He used the term raid or raids to designate the military action on the table, repeating it ten times during his presentation. In describing the anticipated action by France and Britain he informed the cabinet that they will "bomb" ... Egyptian targets with the purpose of "toppling Nasser"; he later used the term "action" to describe the anticipated attacks. Ben-Gurion reserved the term "war" to describe what the enemy might do: "There is apprehension ... that following this raid ... Jordan or Syria or both will launch a war against Israel."9 Clearly, Ben-Gurion was choosing his terms carefully.

The previous week, at the secret Sèvres conference in Paris, where the agreement between the allies was signed, the British explicitly stated that without an Israeli "act of war" Britain would not have the formal reason it absolutely needed in order to intervene as planned. ${ }^{10}$ Ben-Gurion understood the dangers lurking in defining the proposed action as war. Behind the careful terminology lay the emerging body of international law-jus ad bellum (justice to war).

These powerful yet still nascent doctrines explicitly prohibited wars of aggression and strictly regulated decisions to launch wars. ${ }^{11}$ Israel was a party to the UN charter, which outlawed war except for self-defense or pursuant to UNSC (UN Security Council) approval. ${ }^{12}$ At Sèvres, BenGurion bitterly resented the fact that Israel was designated the role of "the aggressor" by France and Britain (while they donned the cloak of using military measures in order to restore peace), and that performing war as an act of aggression (violating jus ad bellum) might result in serious international complications. ${ }^{13}$ His opening remarks were carefully crafted to avoid an Israeli admission, even in the sheltered and secluded cabinet room, that this was the plan. ${ }^{14}$ The ministers, however, were ready to engage. They understood very well the linguistic (hence, legal) significance of choosing a term, and forced Ben-Gurion to face the full thrust of his motion.

Barzilai opened the deliberations with a blistering critique. He immediately named the "elephant in the room": on the table was a motion to go to war. "This motion [is for] an 'initiated war or initiated actions'."15 "We shall be the first to shoot. The first act of aggression will be ours"; he added that, "we are launching an aggression," 16 "we are the aggressors." Barzilai bolstered his argument by contrasting the proposed motion with the 1948 War of Independence, a war of self-defense, with what it was now preparing 
for-a war of aggression. He used the term "war" twelve times in his four and one-half page presentation. The question of the appropriate term for the "motion" was thus on the table.

The remaining ministers wrestled with the problem. Following Barzilai, Bar-Yehuda began by rejecting the term "initiated war", but continued to emphasize that the cabinet was contemplating a war. Rosen followed suit, conceding that "we clearly now want an initiated war." ${ }^{17}$ Bentov twice referred to the motion as a decision to launch a "preemptive war". ${ }^{18}$ Levi Eshkol (P.M. during the 1967 war), supporting the motion, tried to revert to the earlier terminology: "I suggest that in conversations and with regard to the press to beware of the definition initiated war . . this is an act of self defense, we should have no doubt, this is the way it will enter history." 19 Speaking after Eshkol, Meir picked up the hint. Addressing the motion as a "proposed action", she compared it to 1948. Towards the end of the meeting, Ben-Gurion no longer repeated the euphemism of "raid", but cautioned care: "I shall not use the term preventive war. We should not have such thoughts." 20

Clearly, the cabinet was well aware of the nature of the motion and its grave international ramifications, and was willing to confront the harsh reality. Even those who urged avoiding the terms initiated or preventive war understood that it would likely be interpreted as such, and worried about being labeled as aggressors. No one was fooled or blinded as they voted on the motion.

\section{THE STRUCTURE OF THE CABINET'S DELIBERATIONS}

Ben-Gurion opened with a well-structured presentation of the proposal. Following his presentation, a group of skeptical ministers spoke. Two squarely opposed the motion, while others reluctantly supported it-Barzilai poignantly expressed dissent while Bentov delivered his opposing arguments later. Between these two, other ministers offered grave reservations, but did not oppose the motion. ${ }^{21}$

Ben-Gurion then launched a discussion (7 pages), interspersed with interruptions from the skeptical group, offering rebutting arguments and defending the motion. In contrast to his opening remarks, his response to the skeptics appeared to be more candid, revealing his anxiety and deep doubts. As shall be discussed later, he unmasked a crucial factor in this deal: it was an offer he felt he could not and should not refuse. He could not refuse the offer because of the three powers, Israel was the vulnerable agent, 
discreetly obliged to heed the desires of its senior partners; this was true particularly with regard to the desire of France, Israel's generous benefactor. He should not refuse the offer because the expected fruit of success-an overhaul of the international order in the Middle-East was too promising, while the status quo appeared so grim. When Ben-Gurion concluded his rebuttal the floor was taken by his loyal supporters who favored the motion. Unlike the tough arguments presented by the skeptics, the loyalists offered perfunctory arguments and were distinguished by what they did not say. Even though (or because) this group was made of the top party echelon, Israel's major power holders, who understood what was at stake, they limited themselves to platitudes and refrained from engaging the more penetrating arguments made by the skeptics. In keeping with Ben-Gurion's admonition, the loyalists spoke very briefly, and the motion was approved. Following approval, the two dissenters stated that they would remain in the cabinet rather than resign, thereby sharing collective responsibility for the war. ${ }^{22}$

\section{CASUS BELLI: WHY WAR? WHY TOMORROW? THE PRIME MINISTER SPEAKS}

Ben-Gurion's opening remarks (nearly a quarter of the entire protocols) were structured and coherent. He began with a statement of the casus belli, followed by a short report of the military plans of attack, the agreement between Israel, France, and Britain, and finally his concerns. The list of casus belli clearly reveals that Ben-Gurion was aware of international law and implies that jus ad bellum mattered, and that felt obliged Israel to justify the appearance of aggression with arguments of self-defense.

The five casus belli against Egypt all constituted violations of international law. First, Egypt had violated Section I of the armistice agreement since its inception. Second, Egypt violated an explicit UNSC resolution of I95I which held that "There is no state of war between Egypt and Israel." Third, even if a state of war prevailed, international law gave Israel the right of freedom of navigation in the Suez Canal, which Egypt denied it. Fourth, Egypt had organized a special guerilla force, the Fedayeen, and, in collaboration with Jordan and Syria, had been responsible for terrorist raids committed by this force into Israeli territory. ${ }^{23}$ Fifth, Egypt's blockade of the Straits of Tiran prevented free navigation of ships to the Israeli port of Eilat, again in violation of international law. Ben-Gurion did not elaborate on any of these casus belli. He did not explain how Egypt had violated the 
UNSC resolution nor distinguish between the offered reasons that did constitute a valid ground for a war of self-defense (e.g., the organization of the Fedayeen), and those which did not.

Ben-Gurion then stated the motion: "There is a proposal to launch a few raids, ${ }^{24}$ the strategic purpose of which is to conquer the coastal strip adjacent to the straits of Tiran [Aqaba]." 25 He elaborated on the nature of the straits and the military necessity of establishing control not only over the Western coastal strip, but also of strategic points in the Sinai desert itself. He described the Egyptian military presence in the Sinai, reminding the cabinet that Jordan and Syria were in the process of entering into an agreement to unify their military commands under Egyptian leadership. He then linked the casus belli to the motion on the table:

The proposal is - for the violations of the armistice agreements, for violations of international law, for operating the Fedayeen recently and [for] the blockade in the Suez and in the Straits of Eilat we shall conduct a raid tomorrow, the purpose of which is to reach and control the entire coastal strip of the straits, including the two small islands that do not have much value but particularly the island of Tiran. ${ }^{26}$

The island, he continued, was historically under Jewish sovereignty (in the 6th century $\mathrm{CE}$ ), but, this was not the basis for the motion, which, he repeated, was to conduct the "raid tomorrow". ${ }^{27}$

He then presented the tripartite agreement between Israel, France, and Britain:

On Tuesday the governments of Britain and France will address Israel and Egypt and make two pleas: a) to cease the hostilities; b) to refrain from entering the areas of Io miles from both sides of the Canal, and c) to allow British and French forces to occupy key positions along the Canal. And they will request an answer within I2 hours. ${ }^{28}$

He disclosed the content of the Sèvres agreement: on Wednesday morning Britain and France would bomb Egyptian air fields and occupy key positions in the Canal. Furthermore, Egypt's President, Gamal Abdel Nasser, would be overthrown. ${ }^{29}$

Ben-Gurion discussed the plans' ramifications for Israel: France was explicitly committed to supply air cover for Israel's back; Britain agreed in writing not to activate its defense treaty with Jordan if that country used the opportunity to attack Israel; and the British commitment gave Israel a 
free hand to "do whatever we want to do". ${ }^{30}$ Addressing the allies' commitment he stated that he had "no doubts about the sincerity and loyalty" of the French; although he was skeptical about Britain, during the last week he came to trust their commitment to the deal. ${ }^{31}$

Ben-Gurion arrived at the fourth part of the presentation: the pros and cons of the proposed war: "It is possible that we shall encounter problems with the Egyptian army in the Sinai. We may also face hostilities with Jordan and Syria and Iraq." Nevertheless he urged the cabinet to consider the upside:

This is a unique historical opportunity that may never return. Indeed, it is impossible to predict, but in the current international constellation there may not be another situation where two big powers, not as big as America and Russia, but big European powers, take it upon themselves to liquidate Nasser and they can do it and we shall not be partners to this. ${ }^{32}$

After an interruption ${ }^{33}$ Ben-Gurion proceeded to emphasize the danger posed by Nasser, thereby amplifying the value of the proposed regime change: Egypt with a population of 22 million and the charismatic Nasser rapidly spreading his influence across the Arab world would sooner or later attack Israel, and while this attack would end in Israeli victory, it would also be very costly. Joining the allies now would rid Israel of this powerful enemy at relatively little cost. ${ }^{34} \mathrm{He}$ also upped the menace: "Not only the entire Arab world will assist Nasser, but also someone outside the Arab world." 35

Ben-Gurion addressed the two superpowers. According to the allies, the U.S. was not likely to get involved six days before the presidential elections, especially when two of its Western allies were involved. $\mathrm{He}$ then opined that the USSR would remain neutral if the U.S. did not intervene, but added, "Again I say: I do not guarantee this." Complications in Eastern Europe might also deter Russian intervention. However, he cautioned, "Russia has enough power to suppress Hungary ... and to interfere here." 36

He reached the need to abide by the rules of parliamentary democracy. Like Britain and France, Israel needed a formal cabinet ratification before action could be taken: "I told them that the cabinet meeting is on Sunday morning and only then shall we be able to announce our decision." ${ }^{37}$ Why tomorrow as opposed to next week or next year? ${ }^{38}$ Ben-Gurion said not a word about this matter in his introductory remarks; it was only clarified when he re-took the floor to rebut the skeptics. ${ }^{39}$ 


\section{THE CABINET DELIBERATES}

The cabinet deliberations were intense. The skeptical group, both supporters and dissenters, neither adopted the euphemism of "raid" nor were swayed by Ben-Gurion's list of casus belli. ${ }^{40}$ The loyalist group offered tepid arguments in favor of the motion. It appeared that even they shared the foreboding expressed by the skeptics and dissenters.

The cabinet addressed and evaluated six issues related to the impending war: first, the meaning of the tripartite agreement; second, the list of casus belli; third, foreseeable international complications, primarily the reactions of the superpowers; fourth, the philosophy of war and peace; fifth, the likelihood of regime change in Egypt; and, sixth, the preparedness of the home front. The following analysis will weave Ben-Gurion's rebuttal into the arguments made by the ministers, but in the original protocols the entire rebuttal followed the arguments made by the skeptics.

\section{THE TRIPARTITE AGREEMENT}

As Ben-Gurion conceded in his answer to Barzilai's question, but for the allies' intervention he would not have entertained the idea of launching war "tomorrow". ${ }^{41}$ While Ben-Gurion presented the agreement as a unique historical opportunity to improve Israel's position, Barzilai, speaking right after Ben-Gurion, presented a different appraisal. Talking from the standpoint of hardnosed realism, he warned of any delusions of friendship. Friendship and international relations did not sit well with each other.

Britain and France were cynically using Israel, and might not hesitate to drop it in the cold if their interests so dictated. Therefore, Barzilai warned, it would be reckless for Israel to go along: "For a long time England and France have not dared be the first to start [the war], because they do not want to invite American pressure, they do not want to appear as aggressors before the U.N., what do they do-push us to do it." ${ }^{42}$ Barzilai was alluding to the possibility that international developments, particularly U.S. intervention, might lead to a partial satisfaction of Britain and France's interests, and that the two might thereby agree to end the hostilities and ignore Israel's interests.

Other ministers also worried about a possible deal between Britain, France, and Egypt, and raised the specter of perfidious Albion once again betraying Israel's cause. ${ }^{43}$ Only Rosen saw the British involvement as a factor in favor of war: "I am doing this (voting yes), because I . . see this 
as a shift to a new policy not only regarding France ... but with regard to Britain." ${ }^{44} \mathrm{He}$ confessed that he too suspected British sincerity, yet he came to believe that Sèvres represented a turning point in British foreign policy. The reason for his enthusiasm, Rosen made clear, was the sense of relief rooted in the knowledge that Israel was not walking alone.

Unlike Rosen, Carmel rejected the alliance, but approved the war. Like Ben-Gurion, and unlike Barzilai, he thought that war was inevitable because the siege imposed upon Israel by the Arab countries was intolerable. Like Barzilai, he insisted on tough realism. War should be fought only for the purpose of advancing Israel's interests, not to do the bids of other nations, however friendly they may be. For Carmel, the friendship of foreign powers was not a good enough reason to make war, and he warned that it might even boomerang because international public opinion may come to identify Israel as doing the dirty work for the British. ${ }^{45}$ Israeli independence of action, he emphasized, was crucial.

The second dissenter, Bentov, was also underwhelmed by the allure of friendship. For him, the devil was in the details. He posed a sharp question: an appeal (ultimatum, termed "appeal" out of deference to Israel as a partner) by Britain and France to Israel and Egypt to cease fire ten miles from the canal implied an Israeli plan to reach the Canal. However, BenGurion just stated that Israel was not headed to the Suez Canal and was only interested in the Gulf of Aqaba. The appeal therefore was a sham, and would only [and in hindsight, indeed did, PL] expose the collusion between the three parties. ${ }^{46}$ Bentov wanted to know why they should agree to this transparent scheme.

The loyalists, endorsing the tripartite agreement, avoided realpolitik. For them the crucial point was that, after eight years of isolated existence, Israel was in the company of respectable (European) friends. They urged the cabinet to view the agreement as firm and to appreciate the benefits of a move that would improve Israel's international status by creating the coveted new Middle East world order. Eshkol referred to the agreement as "a complete revolution, a change from one extreme to the other." ${ }^{37}$ Meir amplified the point: "I am standing in awe; I cannot fathom what happened there, that suddenly we the meek, the small and humble became a focal point" and she added that while she "trusted France it was almost an obligation ('a mitzvah') to suspect Britain." She also sought to comfort the cabinet with a cold calculation-Britain would keep its word because it "cannot betray us without betraying France". ${ }^{48}$ Aranne echoed her description of Israel as the weak party: "If we were strong we would not need the alliance, but we are weak." He also suggested that Barzilai's realism-the 
suggestion that the allies were using Israel to provide a pretext to go to war, should be turned upside down: Israel was the one using the allies in order to promote its own interests. The allies' attack in the Suez Canal would cause an upheaval, which in turn would divert attention away from Israel's "raids" and thereby provide it with cover. ("Just so", Ben-Gurion interrupted, confirming the point). Aranne also recommended trust in Britain: PM Eden's "personal prestige is hanging on the Suez matter" and therefore it is unlikely that he will not follow through. ${ }^{49}$

Sapir rhapsodized about the relief of associating with such fine company: "This is a historical opportunity that these mighty wish to go along with us." He reminisced about the dearth of weapons during the war of independence compared to the bounty of weapons now supplied by France. ${ }^{50}$ His argument may have been a veiled hint at the fact that the cabinet was approving a cold transaction: France was supplying arms and, as a quid pro quo, Israel was providing a pretext to launch a war. The cautious Sapir did not offer unequivocal support. He confessed that he had "doubts" and was aware of the dangers. There was "anxiety ... hidden in the heart" that the allies might not fulfill their commitment and attack on Wednesday. ${ }^{51} \mathrm{He}$ echoed other practical cabinet members who had difficulty believing that Britain had changed its position overnight.

The cabinet was hard-headed in its appraisal of the Sèvres agreement. Almost all ministers understood its overt blessing and its hidden curse. The repetition of the sense of relief at having the ring of isolation broken, the delight at being recognized as a worthy partner, reveal the anxiety of Israel's elite in the mid-fifties. Isolation was wearing the leadership down, and the cabinet welcomed the newfound goodwill; nevertheless, all understood that underneath the comforting camaraderie lurked the cruel reality of international bargains. First, the newfound British friendship may be short-lived and, second, nothing came for free. The condition required to be accepted into the halls of the strong and mighty, was to accept the role of aggressor.

This dark side of the bargain was highlighted in Ben-Gurion's rebuttal, which on one hand denied the existence of a simple contract-France gave Israel weapons "without political conditions"; 52 while on the other hand, "the initiative (to go to war) did not come from us. If it did not come from there [the allies, PL], it would not have come from me, because I wanted to get more arms." ${ }^{53} \mathrm{He}$ conceded that there was an unarticulated expectation that Israel would abide by France's desire to go to war in order to guarantee the flow of arms. That the negotiations were not among equal partners, and that Israel, the dependent partner, had limited bargaining power, became even clearer when Ben-Gurion explained the choice of the 
date for the invasion (the next day), an explanation he failed to offer during his opening remarks. Five times in the space of two pages he repeated that "We did not decide upon the date", that "The date was chosen by them", and Israel could only say "yes or no". ${ }^{54}$ From Israel's perspective, he said, waiting another six months would have been preferable, but the matter was not in Israel's hands. "They are not in my pocket", he said, again referring to Israel's weakness at the bargaining table. ${ }^{55}$

Commenting on the issue of friendship, Ben-Gurion observed that Israel stood to gain an enormous amount. Nasser would be overthrown (of which he was certain) by the military forces of the two friends, without "one Jew's falling in battle". ${ }^{56}$ Therefore, "Isn't it nice that we perform an act the night before that is unconnected with their action . . . they will use it as a pretext to issue an ultimatum to Nasser." ${ }^{57}$ No one should blame BenGurion for thinking that this was about "being nice". Rather, he offered a hard-headed analysis: the tripartite agreement required that Israel appear as an aggressor before the international community, and that may be a "disaster"; yet at the same time Nasser could be destroyed. On balance, the foreseen gain justified the pain.

\section{THE LIST OF CASUS BELLI}

Of the five causes justifying a war listed by Ben-Gurion, the denial of freedom of navigation through the Gulf of Aqaba was the one that most of the ministers dwelled upon. By implication, they opined that the four other causes failed to qualify as valid reasons to start a war at that time. The guarantee of freedom of navigation to and from the port of Eilat, marginal from the perspective of Britain and France, proved to be the most enduring and powerful achievement of Israel in the 1956 war. ${ }^{58}$

Ministers understood that the blockade needed more in order to qualify as a casus bellum. An actual act of aggression on the part of Egypt was needed in order to ripen the blockade into a right of self-defense. They called it a reason or ground (in Hebrew "Eela"): Israel should have tried to send a ship through the straits. Only when Egypt activated the blockade and prevented passage would Israel's right of self defense spring to life. The term "reason" or "ground" was used in two separate contexts throughout the deliberations. The allies demanded that Israel go to war, thereby supplying them with a reason to intervene without appearing as aggressors. Besides supplying a ground of action to others, Israel itself needed a reason to start a war and show that it was not in flagrant violation of international law. In 
addition to resenting the need to supply the allies with a ground for action, with a keen awareness of international law, some ministers were worried about the absence of a justification that might absolve Israel of the charge of aggression. Like Ben-Gurion, the ministers were sensitive to the ways jus ad bellum applied to the case at hand.

Ben-Gurion had already introduced the issue in his initial presentation, but he was referring to navigation through the canal, not the Straits of Tiran, proving perhaps that the canal was the focus of the war, as required by Britain and France: "There was a suggestion that maybe we should try to send a ship through the Suez Canal and they (the Egyptians) will deny it passage. This would be a reason to conduct the raid." A consultation with Carmel, made clear that there was no time to execute the plan and it was shelved. 59

The ministers made various suggestions for an appropriate "reason" to launch a war, thereby implying that Ben-Gurion's five causes were not persuasive. Shapira, fearing that Israel might be portrayed as an aggressor, suggested that Israel use the recent establishment of a Unified Arab Command under Egyptian leadership as casus bellum. "We should file a complaint in the Security Council, claiming that the unified command amounted to a declaration of war. That way we shall be justified in taking action." ${ }^{60}$ Bentov rejected this idea, and re-emphasized the Aqaba blockade as the only plausible ground to launch war: "We need to do the maximum to give the world the impression that this is the reason for the war." $\mathrm{He}$ emphasized his frustration at the fact that the Ministry of Transportation failed to arrange for "a ship [that] will break through the blockade and that they will detain it, that they will shoot at it." ${ }^{11}$ At the end of the debate, Eshkol picked up on Bentov's idea, but challenged the argument that it would have provided a superior justification: "They [the Egyptians] could have let the ship pass, and thereby preempt the reason [to launch a war]." 62 Eshkol's argument was pragmatic and impatient of technicalities. A "reason" was a cover-up, and not a true cause. Because it was likely to fail it was useless. The appearance of legality was not material. For Eshkol, a staunch Ben-Gurion loyalist, the justification to go to war was rooted in the "opportunity" the war provided for improving Israel's circumstances. This was both the true and the sufficient reason. ${ }^{63}$

Overall, it seems that the casus belli were not perceived by the cabinet as persuasive or even necessary. There seemed to be a tacit understanding that Israel was going to war in order to abide by the tripartite agreement. Ministers also understood the significance of jus ad bellum, and most hoped a way could be found to present Israel as adhering to the emerging norms 
of the law of war. At the same time, they were swayed by the benefits a successful war might produce for Israel: regime change in Egypt, defeat of the Egyptian army in Sinai, acquisition of territory along the coastal strip of the Gulf of Aqaba which would guarantee free navigation to Eilat, and alliance with the European powers, kindling hopes of acting as "almost" equal partners in engineering a new Middle East order.

\section{INTERNATIONAL COMPLICATIONS}

Barzilai, taking the floor after Ben-Gurion, interpreted the tripartite agreement in the context of the broader international scene. Why did Britain and France need Israel? Because they worried about U.S. pressure and looked for a scapegoat. He warned about the U.S. reaction to the invasion, and dismissed as mere speculation Ben-Gurion's assessment that the Presidential election campaign would distract the U.S. Barzilai predicted that U.S. pressure could yet undo any future military gains opining [correctly, in hindsight] that it would use the invasion to augment its international role as a "champion of peace", and make "decisive political moves" against Israel. ${ }^{64}$ U.S. pressure on the European parties could leave Israel in precisely the situation it dreaded: alone in the battlefield. Even France, considered by Ben-Gurion as Israel's true friend, may change course if the U.S. could persuade Nasser to terminate his interventions in Algeria. ${ }^{65}$

Barzilai focused on the USSR. The complications in Hungary and Poland were not so great as to rule out Soviet intervention [also correct in hindsight]. The USSR had enough resources to intervene both in Eastern Europe and in the Middle East. An invasion of the Sinai may even give the Soviets the excuse they needed to gain influence in the Middle East. ${ }^{66}$ $\mathrm{He}$ added that the Bandung group of Asian and African nations, which recently opposed colonialism and imperialism, would react with hostility against Israel. ${ }^{67}$ Bentov also called attention to the U.S.: "After the elections, the U.S. may, together with other powers, insist that we withdraw, this danger is real." 68

Ben-Gurion admitted that he too was worried:

Most of all I am worried about America. America will force us to withdraw. America does not need to send military forces. America can say that she is breaking diplomatic relations, stopping Israeli fund raising, loan guarantees, and more, she will consider what's more important to her-we or the Arabs, that we shall be in her camp or that she will be against us. 
He could not predict how Eisenhower, if elected for a second term (very likely at that point) would react. ${ }^{69}$ This analysis, almost an accurate forecast of future events, is astonishing. Ben-Gurion and the cabinet had a very good grasp of the international scene; they were fully aware of the risks, and yet decided to go forward. The proof that the U.S. factor was well understood, and only obscured for fear that it would tilt the scale in favor of prudence, is found in the analysis of the loyalists, whose discussion followed Ben-Gurion's rebuttal. Neither Eshkol, nor Meir, both practical leaders intimately familiar with the extent of Israel's dependence on the U.S., mentioned the superpower. Instead, they emphasized the extraordinary fortunes that would befall Israel should the "opportunity" materialize into gains. While silent about the U.S., they did discuss the dangers posed by the USSR, as if attention to the USSR would spare deliberation about the U.S. It may well be that the loyalists accepted the inevitability of "war tomorrow", and therefore concentrated on the promise of the expected gains. However, it is important to realize that Ben-Gurion disclosed his astute estimate of what was to come and that the cabinet understood the risks taken.

Meir, whose cabinet role should have required analysis of the international scene, and who was savvy about international affairs, defended the plan in generalities, "the world" would condemn Israel, but "we shall overcome". To justify the war, and strengthen the cabinet in expectation of world condemnation, she revived the narrative of the 1948 war. Then, as now, Israel had been fighting for survival and had no choice but to weather the storm:

I am not ashamed for this to be recorded in the protocol, that if I have to choose between these two things [death or survival, PL], I am willing to receive a condemnation even from the UN, even from ... all the heads of states, the decent and the indecent and stay alive. ${ }^{70}$

She understood the impending international outcry and implicitly urged the cabinet to accept it with no feelings of guilt.

Sapir further diverted attention away from the U.S. to the USSR: "I see the greatest danger in a covert Russian intervention against us. Russia will experience Nasser's defeat as its own" He added that one could not tell how the political chaos in Jordan or the unrest in Syria might affect the situation. ${ }^{71}$ Despite his fears he supported the war. The tactical reasoning by the group of loyalists-all well acquainted with the significance of the U.S. for Israel's survival—is an indication of the dynamics of decision making 
in the cabinet. Whether determined to suppress the reality in order to calm their own fears, or aware that the opportunity for reversal was not on the table, the loyalists seemed either to have placed support of the prime minister above their keen understanding of Israel's interests, or to have trusted their leader to know better.

\section{A MATTER OF PRINCIPLE: WHEN SHOULD THE NATION GO TO WAR?}

Barzilai first introduced the point: "I must return to . . . principles, you [Ben-Gurion] have explained it best . . . : a shaky peace is always better and preferred to victory in war, not to war, but to a victory in war". War meant loss of life and limb, the sacrifice of "an entire young generation" (as experienced in the war of independence, PL) with no guarantee of peace. A "third round" between Israel and its neighbors was foreseeable, even if this war ended in victory. Barzilai reminded Ben-Gurion that he himself had theorized that only a political solution, not a war, could resolve the Arab Israeli conflict, and that in the past he (Ben-Gurion) pledged that Israel "shall never start a war." 72

Barzilai asked Ben-Gurion to account for the theory of war and peace that he had previously elaborated upon, ${ }^{73}$ that war was linked to death, that a government was bearing the awesome responsibility to preserve the life of the young generation. ${ }^{74} \mathrm{He}$ later referred to Ben-Gurion's assertion that this war would be short: "Who guarantees that there will not be a conflagration ... even if the chance is small, are we allowed to take the risk?"75 Better keep the shaky peace, he concluded. ${ }^{76}$ His insights struck a chord and ignited a lively debate.

An interesting aspect of the debate was how Barzilai's words were twisted. Whereas he stated that "a shaky peace" was better than war, BarYehuda changed the term to "bad peace", stating that he would not necessarily prefer a bad peace to a war. ${ }^{77}$ On his mind was the Jewish experience in WW II. The bad peace with Nazi Germany "only secured our destruction". ${ }^{78}$ Hence, choosing between war and peace was not a matter of principle but rather contingent upon context. Yet Bar-Yehuda refrained from analyzing the pending circumstances. The matter was already decided: "We are not asked to decide prospectively but rather retroactively." 79

The cabinet addressed the desirability of a "bad peace over war" — rather than "a shaky peace compared to war". Barzilai, perhaps realizing he was outnumbered, or losing perspective of the difference in the heat of the debate, 
did not correct his fellow ministers. Carmel picked up the theme. "I agree with the formula that a bad peace is better than victory", but he pointed to exceptions. A bad peace may lead to war under worse circumstances. $\mathrm{He}$ opined that war in the near future was inevitable because the "belt around us is tightening so that the danger for the destruction of the state increases daily." Therefore, it was preferable to launch a war now when the circumstances were more favorable. As to victory, Carmel argued that a military victory was always better than defeat. ${ }^{80}$ The task at hand was to prevent further changes in the status quo. The Arab countries were tightening the siege around Israel and time was on their side. It was better to strike now. Bentov rejected this view and reintroduced the principle that only political solutions were stable: "In general I do not believe that a small nation can resolve any problem through war. Every problem resolved will yield graver problems." Ben-Gurion interrupted, and the following exchange took place: "One problem, God forbid, may be resolved to destroy us"-Bentov, "So it will resolve the problem of the other side"-Ben-Gurion, "We need to make sure there will be no such war"-Bentov, "This is a long term problem. We are now speaking about short term problems."

The gist of the disagreement between the two was survival. Ben-Gurion saw every war, even one initiated by Israel, as involving Israel's survival. Bentov urged a distinction between different kinds of war, and saw the proposed war as related not to survival but rather to benefits that may or may not materialize. Ben-Gurion agreed that, "We know how we start, but there is no guarantee how it will end." $81 \mathrm{He}$ admitted that the territorial gains he discussed in his opening remarks might not materialize. He now offered a different benefit: the war might bring about a quiet period of five to eight years that would enable Israel to invest in domestic building: "When I weigh on the one hand the chances of constructive work, and on the other hand the possibility of struggle and war, then the quiet work is decisive." He predicted that Nasser's overthrow would grant Israel a period of "passive peace", a welcome development. ${ }^{82}$ Eshkol and Meir returned to the notion of a "bad peace". "We are increasingly under siege", Eshkol echoed Carmel's point, and this could only end in a "bad peace". He did not see a partner with whom to strike a "bad peace" deal. Egypt was planning to attack Israel, i.e., it had no interest in maintaining the conditions of a "bad peace". ${ }^{83}$ Meir reiterated Eshkol's point calling the "bad peace" an "unguaranteed luxury". The Arab countries would destroy the "bad peace" at the appropriate moment.

The cabinet deliberations veered between the general and the particular. The skeptical ministers emphasized the matter of principle-war 
was risky, unpredictable surprises and complications might arise. Unless absolutely necessary, it was preferable to keep the status quo. Even a military victory, they emphasized, might not yield the desired political solution. Ben-Gurion's loyalists emphasized the logic of preemptive war: a bad peace gives the enemy time to prepare for war. Ben-Gurion was in the middle, conceding the validity of the principle, but pushing for an exception to the rule because this war presented an "opportunity" to improve Israel's strategic situation. The meaning of a "shaky peace", with its implication that perhaps diplomacy could lead to a political solution, was frozen in the icy realization that war was inevitable. In a collective act of "reducing dissonance", the cabinet dismissed the faint promise of diplomacy and adopted the pessimism inherent in the reality of war.

\section{LIKELIHOOD OF REGIME CHANGE}

Ben-Gurion made it clear that overthrowing Nasser was enormously important and tempting. ${ }^{84}$ None of the ministers in the ensuing deliberations doubted the dangers inherent in Nasser's leadership or the legitimacy of perpetrating a regime change by external force. Some doubted the likelihood of regime change or expressed fears about the aftermath of such an overthrow, even if it came to pass. Barzilai argued that "It may well be that Nasser will depart"; from his place in exile he "may also establish a shadow government, he may launch an unending guerrilla war." Who could tell what policy "his replacement will choose". Egypt's next ruler may decide to appease the West by displaying cooperation on the Suez Canal issue or even on Algeria. While doing so, this next ruler may adopt a harsh position against Israel (Barzilai referred to an anti-Semitic policy thereby equating an anti-Israel position with anti-Semitism). Under these circumstances the appeased West may turn its back to Israel. ${ }^{85}$

Ben-Gurion ignored Barzilai's warnings. He twice expressed his "trust" that Britain and France were determined to remove Nasser, and that they had the military power to do so. But he cautioned not to see regime change as a fait accomplis: "A different government may emerge in Egypt, I do not know, I do not give this as part of the dowry, nobody can tell what will happen there." 86 The matter was not extensively deliberated even though it was a major aim of the proposed war. It may well be that the ministers had too much trust in the "mighty" European powers, and could not fathom that the task would not be accomplished. It could also be that wishful thinking took hold of them, helping turn a blind eye to Barzilai's warnings 
and Ben-Gurion's concession. The cabinet could not ponder alternative scenarios to the rosy one presented by Ben-Gurion.

\section{THE PREPAREDNESS OF THE HOMEFRONT}

In his initial presentation, Ben-Gurion mentioned that Israel lacked adequate protection against a possible Egyptian air attack, and that France had committed its air force to protect the rear should an attack take place. Barzilai and Bar-Yehuda both protested that the homefront was not adequately protected because there were not enough shelters and hospitals. Ben-Gurion urged the cabinet not to address the matter "now" and the matter indeed was dropped until after the vote.

\section{CONCLUSION}

This article is one part of an ongoing research project. The emphasis on small in the title- a small nation goes to war-should now stand out as an important aspect of the decision-making process. In the second half of the twentieth century the place a country occupied in the larger international scene made a difference. The protocols leading to the fateful decision to go to war reveal a sober and earnest process of deliberation, where much of the information was placed on the table, and where deep and searching arguments were considered. The vulnerability of Israel on the international scene appears to have served as the ultimate push to authorize the invasion.

Israel emerged with a few gains from the 1956 war that were not foreseen by either Ben-Gurion or the cabinet. The gains should be attributed to Ben-Gurion's ability to change course in light of the United States' fierce disapproval, and to the fine diplomatic campaign led by Meir and Eban, a campaign that galvanized U.S. public opinion in support of the small and vulnerable Jewish State. It may well be that without diplomacy, international ire might have seriously traumatized the fledgling polity.

It is important to consider not only what was said, but also what was omitted. Two important issues were not mentioned. First, the fact that at the end of the Sèvres meeting the French promised Israel a big rewardassistance in building a peaceful nuclear plant in the Negev. Ben-Gurion did not report this to the cabinet. Second, the entire protocols do not mention the Egyptian Jewish community. The Jewish state, looking backward at the horrific catastrophe of the Holocaust and forward to building a strong, 
defensible Israel, did not pause to consider the fate of Egyptian Jews. They were expelled by Nasser shortly after the invasion and thereby came an end to the Jewish community in Egypt.

\section{Notes}

1. I wish to thank Natan Aridan and David Kretzmer for valuable comments and suggestions, Mordechai Bar-On and Motti Golani for enlightening discussions, and Rivka Brot for expert research. The article does not address the intricacies that propelled Britain and France to go to war. Suffice it to say that Nasser's nationalization of the Canal in the summer of 1956, coupled with his support for the rebellion against the French in Algeria, gave the two European powers enough motivation to use force. Simultaneously, France and Israel were intensifying their relationship, with France becoming Israel's major supporter and arms supplier. There is voluminous literature on this subject. See, e.g., Motti Golani, Israel in Search of a War (Brighton, UK, 2007) (Hebrew edition contains two volumes, published by Maarachot); Natan Aridan, Britain, Israel and Anglo-Jewry (London, 2004); Mordechai Bar-On, Of All the Kingdoms: Israel's Relations with the United Kingdom During the First Decade after the End of the British Mandate In Palestine, 1948-1958 (Jerusalem, 2006) [Hebrew]; S. Ilan Troen and Moshe Shemesh eds., The Suez-Sinai Crisis: 1956 (London, 1990); Michael Brecher, The Foreign Policy System of Israel (Oxford, 1972); Zeev Maoz, Defending the Holy Land (Ann Arbor, MI, 2006); Benny Morris, Israel's Border Wars, 1949-1956 (Tel-Aviv, 2003) [Hebrew]; Avi Shlaim, The Iron Wall (New York, 200o); Gabriel Sheffer, "Sharett, Ben-Gurion, and the 1956 War of Choice," Medina Umimshal, 5 (1988). There are also several memoirs from this period including by David Ben-Gurion, Moshe Dayan, Shimon Peres, Abba Eban, and Gideon Raphael.

2. E.g., Gad Yaacobi, The Government (Tel-Aviv, 1980) 214-6 [Hebrew]. This book, typical of the period, states that the motion to launch a war approved a fait accomplis but does not mention any cabinet deliberations. Golani methodically reviews the processes leading to the war but does not refer to any cabinet deliberations, presumably because the cabinet protocols were still classified.

3. I wish to thank the team at Israel's archive for their professional help. The protocols are on file in my personal archives. See also State of Israel, Israel State Archives, Yemima Rosenthal (ed)., Documents on the Foreign Policy of Israel, I2 (Jerusalem, 2009) 5. The volume includes rich documentation of the Suez War but does not include the protocols documenting the decision to go to war. Hereafter: Protocols.

4. The protocols pose the cardinal question of constitutional governance: what institutional and procedural method should guide a nation as it contemplates war? 
This question is intimately linked to the question of the role of law; what, if any, role did legal notions and principles play in the deliberations authorizing the war?

5. The Israeli arrangement has followed that of the U.K. Westminster model. Prior to the Suez War, the I9 Cabinet members under PM Anthony Eden formed an "Egypt Committee", which ultimately decided to validate the Sèvres agreement and go to war. Eden headed the 7 member committee. See Colin Seymour-Ure, "British 'War Cabinets' in Limited Wars: Korea, Suez and the Falklands," Public Administration, I8I (2007) 62.

6. Ben-Gurion returned from Sèvres late on Wednesday 24 October. As minister of defense he had four days to prepare his military for the attack and to persuade his cabinet to vote for launching the war. There is a theory that he preferred to wait until the conventional Sunday meeting in order to prevent a leak about the top secret impending plan (Yaacobi, The Government 215). It is equally likely that no meeting could be fruitfully held prior to Sunday. The Sabbath, beginning on Friday afternoon, practically precluded the participation of the members of the religious party and, more importantly, Ben-Gurion knew well that his cabinet was skeptical of the idea of war and needed time to secure an affirmative vote. During the deliberations he referred to the wrenching discussions with individual ministers. It is also possible that he calculated that the cabinet, facing the decision to "go to war tomorrow" would bend to pressure to approve the motion so as not to upset Britain and France, who presumably relied on Israel and made their own preparations for the invasion.

7. The Hebrew original, "there is a motion to conduct an action of several raids", is grammatically awkward in as much as Ben-Gurion implicitly concedes that this is an action which, in fact, comprehends several actions, and that the designation "action" in the singular is designed to mask the breadth of the proposed activity. The date was dictated by Britain and France, and appears to have been reluctantly accepted by Ben-Gurion.

8. See, e.g., Eyal Kafkafi, The Sinai Campaign-A Diplomatic History (Tel-Aviv, 1994) [Hebrew]; Morris, Israel's Border Wars 255-66; Gabriel Sheffer, Moshe Sharett, Biography of a Political Moderate (Oxford, 1996); Resolution versus Management of the Middle Eastern Conflict: Moshe Sharett and David Ben-Gurion (Jerusalem, 1980).

9. The concern was rooted in the existence of a mutual defense treaty between Egypt, Jordan, and Syria. Particularly worrisome was the defense treaty between Jordan and Britain, which would have required Britain to intervene in a case of war between Jordan and Israel. Ben-Gurion reported that Britain guaranteed that it would not intervene if "Jordan attacked Israel". These remarks clearly suggest that he was well aware of the differences between preemptive, preventive, and defensive war. Later Ben-Gurion described the "apprehended" Jordanian reaction as a "sudden attack", and explained the security measures taken to address it. Protocols, 5 .

10. Mordechai Bar-On, Challenge and Quarrel: The Road to Sinai-1956 (SedeBoker, 1991) 259 [Hebrew]. From the perspective of international law there is no 
difference between a war and a "raid" — both are forbidden subject to the exceptions delineated in the UN Charter (below, n. II). However, the policy of Israel's government was to conduct "raids" or limited combat operations, justifying them as acts of "self-defense". When Ben-Gurion used the term "raid" rather than war here he was both referring to a practice that has become expected, if not condoned by the international community, and even wrapping it in the rationale of self-defense associated with legitimacy in the Israeli mind. For the history of raids in the years following Israeli independence see Morris, Israel's Border Wars.

11. "The United Nations Charter generally prohibits the use of force (Article 2(4)) with two exceptions: force may be used by states acting in individual and collective self-defense (Article 5I) and force may be used when authorized by the Security Council (Article 39, 42)." Mary Ellen O'Connell, International Law and the Use of Force, Cases and Materials (New York, 2005) 240.

12. Idem.

13. Bar-On, Challenge and Quarrel 259-6I, Golani, Israel in Search of a War $364-74$.

14. Chief of Staff, Moshe Dayan came up with the idea that Israel would launch a deep and powerful raid that would have enough attributes of war to satisfy the British demand while allowing Israel to claim that it was merely continuing its previous policy of conducting occasional raids across its borders. This verbal solution also explains the dubious grammar in "an action of several raids", infra n. 20. See Bar-On, Of All the Kingdoms, 267.

15. Protocols, II.

16. Ibid., I2.

17. Ibid., 20.

18. Ibid., 24.

19. Ibid., 34 .

20. Ibid., 38 .

21. I refer to these ministers as "The skeptical group". They included Barzilai, Bentov, Bar-Yehuda, Rosen, Shapira, and Carmel (in order of appearance).

22. Protocols, 4I. Ben-Gurion: ". . . what does it mean that you are opposed, are you staying in the government and accepting responsibility?" Barzilai: "I wish this issue to be stated without doubt, that we see ourselves as responsible out of cooperation and collegiality one hundred percent. We expressed our opinion, voted in accordance with our judgment and conscience, we think that this is a grave matter, but we shall carry the burden of responsibility."

23. The word terrorist did not appear in the protocols.

24. The literal translation is "an action of several raids" - "peulat pshitot achadot", Protocols I. See Morris, Israel's Border Wars, for a discussion of the role of "raids" in Israeli military and foreign policy during the r950s.

25. Protocols, I: "There is a proposal to launch an action of several raids, the strategic purpose of which would be the conquest of the coastal strip of the straits 
of the Sea of Reeds, seizing the forts on along the coast, I shall tell you which are the forts-"

26. Protocols, 3 .

27. Idem. True to the Zionist narrative of "return" to the land of the forefathers, Ben-Gurion could not resist recounting the historical claim to the islands.

28. In the general literature this "appeal" is known as the "ultimatum", but at Sèvres the decision was to refer to it as "an appeal" out of respect towards Israel, which was placed in the paradoxical situation of being both a partner to the agreement and a recipient of the ultimatum.

29. Ibid., 4 .

30. Ibid., 5 .

31. Ibid., 6.

32. Ibid., 7 "There was a proposal to make us partners but we refused."

33. Idem. Rosen: "Why do you say that we shall not be partners in liquidating Nasser?" Ben-Gurion: "because they will do so by themselves."

34. Ibid., 7 .

35. Ibid., 8.

36. Idem. Ben-Gurion estimated that "The Soviets were speculating that they will complete their interventions in Eastern Europe before the elections in the U.S."

37. He ended his speech by raising concerns about the possibility that Jordan would attack on Tuesday and that the Jordanian border with Israel was long, and discussed precautionary measures, Protocols, 9.

38. In this rebuttal, Ben-Gurion emphasized several times that he would have preferred to wait another six months. Mordechai Bar-On, who was present at Sèvres, recounts that Ben-Gurion pleaded for one more day "to leave us four days of preparations", but the French rejected his request emphatically; Challenge and Quarrel 276.

39. See discussion below.

40. Carmel, Protocols. 22. "We need to act in order to prevent a change in the status quo against us ... but ... I would not want the world to get the impression that we initiated this."

41. Barzilai, Protocols, I3, "There are a lot of urgent matters pressing us . . . between us, if this lucky occurrence [the agreement, PL] would not have emerged, would you at this moment suggest a raid on the straits of Eilat?" Ben-Gurion: "No".

42. Protocols, II.

43. Ibid., I6.

44. Ibid., 19 .

45. Ibid., 23. Carmel does not mention France. He studied in France and was a member of the St. Germain delegation, which first explored the possibility of a joint attack on Egypt. Golani, Israel in Search of a War 257.

46. Ibid., 25

47. Ibid., 34 . 
48. Ibid., 36 .

49. Ibid., 38 .

50. Ibid., 39 .

51. Idem.

52. Protocols, 27.

53. Idem.

54. Ibid., 29.

55. Ibid., 32: "I am not to blame that this matter was 'cooked' in the last minute, do you think that they are in my pocket?"

56. Ben-Gurion repeated this twice (Protocols, 29), implying that the work will be done by others. Evidently by "Jew" he meant Israeli, as it was quite possible that the British and French troops included Jews. See also below-the fate of Egyptian Jews was not mentioned.

57. Protocols, 29.

58. However, Nasser persisted in refusing to recognize Israel's right (even though he did not interfere with actual navigation after May 1957). His blockade of the straits in 1967 led to the Six Day War. Maoz, Defending the Holy Land 80-2.

59. Protocols, 8.

60. Ibid., 2I: "The world should know that we see the unified command now as a threat to our . . . life."

61. Bentov thought the Unified Arab Command could not provide adequate grounds for attack, because the Command did not issue any threat to Israel. He offered no details, but it appears he was talking about breaking the blockade of the straits of Aqaba, not the refusal of passage through the Suez Canal, Protocols, 24.

62. A curious exchange between Eshkol and Bentov proved that Eshkol did not study the matter of such a ground for attack before the cabinet meeting: Eshkol: "But even if there were ship_a strange thing might have happened, in the past they already permitted a ship to pass (Bentov: "Not under Israel's flag.") —I think it has happened once. It would have been best if they did something last night." It was not clear what he was referring to, Protocols, 34 .

63. Unlike other fellow ministers, the loyalist Eshkol searched for legal justifications to validate the action.

64. Protocols, I2. Barzilai added, "What will the Democrats say during the campaign: you [Eisenhower, PL] bragged that you are putting off a great fire, before the elections, under your nose they are arranging a big conflagration."

65. Idem.

66. Idem. "When we start an aggressive act, a good opportunity is created for the Soviets to intervene . . . if America does not want and cannot enter into a conflict with Israel, it will make it easier for Russia to intervene here."

67. Ibid., I4.

68. Bentov did not speak in full sentences but in fragmented remarks. His literal words were: "I fear that matters will look differently after the elections in America. They will reach an agreement with Egypt. I do not know what problems might 
arise, India, or oil or something else. Shall we not confront a situation that these superpowers together with others will demand our withdrawal? I am talking about a real danger." Protocols, 26.

69. Protocols, 32.

70. Golda Meir, born in Russia but raised in the US, prized America and was a great believer in Israel's need to cultivate good relations with the Western superpower. At the St. Germain meeting, which preceded the Sèvres conference, she emphasized the importance of not working behind the Americans' back. Her silence in this matter reflects her loyalty to Ben-Gurion. She decided to take the risk, subordinating her better judgment to his.

71. Protocols, 37-8. Meir also mentioned the USSR, emphasizing its double standards. "It may, indeed, come to Egypt's help, but it would not assist Israel if Egypt were the aggressor." Protocols, 35 .

72. Protocols, I3.

73. Stung, Ben-Gurion interrupted Barzilai: "Wait a minute. You may know that I offered conquest of the straits and my offer was rejected, this could have also led to war." Barzilai: "Allow me to say this and you know it: in any event this would have been a dangerous raid and I think it is good we did not do it." Ben-Gurion: "This is subject to different views," Protocols, I3. The previous year, a proposal by Ben-Gurion to conquer the straits was rejected by the cabinet, Golani, Israel in Search of a War 98-Ioo.

74. Barzilai may have been alluding to the 1948 war where approximately 6,000 men and women died in battle, one percent of Israel's youth had lost their lives. Retrieved from http://www.mfa.gov.il/MFA/History/Modern+History/ Israel+wars/Israels+War+of+Independence+-+1947+-+1949.htm [last visited on I5.2.20IO]. Compare to the bloodiest war fought by the U.S.A., the civil war, where $2 \%$ of the population at the time died in battle.

75. Protocols, I4.

76. Ibid., I3.

77. Ibid., I5. There is a Hebrew play on words here that is hard to capture in translation. Barzilai's term was "shalom ra-oo-a," A shaky peace. Bar-Yehuda shortened the terms "shaky" — "ra-oo-a"—-to "bad" "ra", thus referring to a condition of "shalom ra" bad peace.

78. Idem.

79. Ibid., I6. Bar-Yehuda also added that he agreed with many of Barzilai's arguments and found them compelling.

80. Ibid., 24 .

81. Ibid., 31.

82. It was not clear whether Ben-Gurion had in mind the categories of shaky vs. bad peace in this context, Protocols, 32 .

83. Ibid., 34. "In recent weeks there is always a feeling that we are surrounded, this is a basis for a bad peace ... if Egypt will occupy Jordan the world will see . . . what our life amounts to." 
84. Ibid., 4. "The target is to terminate Nasser's rule." Protocols, 8: "If we don't, we shall sooner or later confront Nasser, but under totally different conditions, isolated, whereas behind him stands the entire Arab world and also some beyond the Arab world."

85. Ibid., I3. Barzilai continued, "Under such circumstances I am not so sure that Dulles will repeat his compromising offers to us, he will have the advantage of criticizing us as aggressors. In any event he will have a condemning argument." 86. Ibid., 3I, 32. 